\title{
Työelämätaidot korkeakouluopetuksessa
}

\section{Opiskelijoiden kokemuksia asiantuntijuuden ja taitojen kehittymisestä monialaisella kaupunkitutkimuksen projektikurssilla}

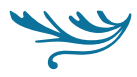

Korkeakoulut ovat yhä kiinnostuneempia kehittämään opiskelijoiden työelämätaitoja tutkintokoulutuksessa. Millä tavoin taidot kehittyvät tieteidenväliseen työskentelyyn perustuvalla projektikurssilla? Opiskelijat

kuvaavat oppimistaan suhteessa monialaisuuteen ja oman alansa asiantuntijuuden kehittymiseen.
\end{abstract}

\section{У}

KORKEAK OULUOPETUKSESSA On 2010-luvulta alkaen alettu kiinnittää yhä enemmän huomiota tutkintojen ja opetuksen osaamisperustaisuuteen ja työelämärelevanssiin eli -vastaavuuteen (Kullaslahti \& Yli-Kauppila 2014; Mäkinen \& Annala 2012; Virtanen \& Tynjälä 2013). Työelämätaidot ovat olleet perinteisesti aikuiskasvatuksen ydinaluetta, josta korkeakouluissa ovat vastanneet tyypillisesti erilliset täydennyskoulutusyksiköt. Samaan aikaan kun korkeakoulut ovat 2010-luvulta alkaen yhtäältä yhä virtaviivaisemmin keskittyneet ydintehtäviinsä - erityisesti tutkintoihin johtavaan koulutukseen ja tutkimukseen - ja ulkoistaneet tai yhtiöittäneet täydennyskoulutusyksiköitään, tutkintokoulutus on suuntautunut entistä enemmän työelämässä tarvittavien taitojen tuottamiseen ja lähestyy näin monilla aloilla perinteistä aikuiskoulutuksen maailmaa. Näin on ollut erityisesti kaupunkitutkimuksen, -suunnittelun ja -kehittämisen alalla, joka on tämän tutkimuksen konteksti (Mattila 2009; 2013).

Edellä kuvattu kehityskulku on lisännyt korkeakoulujen kiinnostusta projektikursseihin ja ilmiö- 
pohjaisiin kursseihin, joissa oppimisen lähtökohtana toimivat todellisen maailman ilmiöt ja joissa ilmiöiden ymmärtämiseen ja toisinaan myös hallintaan liittyviä tietoja ja taitoja opetellaan tieteenalarajat ylittäen (Lonka ym. 2015).

Tämän artikkelin lähtökohtia määrittää myös työelämätaitojen kehittämiseen perehtyneiden Seija Nykäsen ja Päivi Tynjälän $(2012,17)$ näkemys, jonka mukaan työelämätaitoja koskeva tutkimusteema nähdään osana "aikuiskasvatusta ja aikuiskasvatustiedettä, koska tämä tieteenala kohdistuu aikuisen oppimisen ja koulutuksen kysymyksiin (Collin \& Paloniemi 2007) ja koska korkeakoulujen opiskelijat ovat aikuisiässä”.

Kun työelämän tarpeisiin suoraan vastaamaan pyrkineen aikuiskoulutuksen perinteiset tehtävät ovat siirtyneet korkeakoulujen tutkintokoulutukseen, pedagogisia haasteita ja jännitteitä oppimisen eri tavoitteiden välillä ei ole voitu välttää.

Useimmissa Suomen yliopistoissa otettiin 2010-luvulla käyttöön uudet, aiempaa laaja-alaisemmat kandidaatti- ja maisteriohjelmat, joissa painottuu yhtäältä työelämässä tarvittavan laaja-alaisen ja tieteiden välisen osaamisen tuottaminen, jolloin 'tieteidenvälisyydellä' tarkoitetaan perinteiset tieteenalarajat ylittävää ja niitä kyseenalaistavaa tutkimista ja oppimista, eikä siis vain monitieteisyyttä eli usean tieteenalan läsnäoloa koulutusohjelmassa (Mikkeli \& Pakkasvirta 2007, 65). Toisaalta oman alan asiantuntijuuden syventämisen katsotaan edelleen olevan keskeinen osa yliopisto-opetusta. Tutkimuksessa paneudumme tähän asetelmaan konkreettisen aineiston avulla. Vastaamme kvalitatiiviseen analyysiin pohjautuvassa artikkelissamme kahteen tutkimuskysymykseen:

1) Miten opiskelijat kokivat ilmiöpohjaisen, tieteidenväliseen työskentelyyn ja tiedon käytännölliseen soveltamiseen tähtäävän projektikurssin kehittäneen työelämätaitoja erityisesti kaupunkitutkimuksen, -suunnittelun ja -kehittämisen viitekehyksessä?

2) Miten opiskelijat kuvasivat oppimistaan suhteessa monialaisuuteen, tieteidenvälisyyteen ja oman alan asiantuntijuuden kehittymiseen?
Artikkelimme vastaa haasteeseen, jonka mukaan tarvitaan lisää kvalitatiivista tutkimusta opiskelijoiden kyvyistä tunnistaa omaa osaamistaan (ks. esim. Tuononen ym. 2017, 240).

Analyysimme aineisto on kerätty kahdella kurssilla, jotka ovat osa Helsingin yliopiston ja Aaltoyliopiston yhteistyönä toteuttamaa "Suunniteltu ja koettu kaupunki" -kurssisarjaa. Kurssien suunnitteluun ovat vaikuttaneet keskeisesti näiden kahden yliopiston uudet, kaupungistumisen haasteita analysoivat ja niihin vastaamaan pyrkivät hankkeet, kuten Helsingin, Espoon ja Vantaan kaupunkien kanssa rakennettu Kaupunkiakatemia sekä uudet maisteriohjelmat Urban studies and planning (HY ja Aaltoyliopisto) ja Spatial planning and transportation engineering (Aalto-yliopisto).

"Suunniteltu ja koettu kaupunki" -kurssien tutkimuskenttänä on ollut kaupunkiympäristö. Niiden tavoitteena on ollut rakentaa ja kokeilla uusia kaupunkikehittämisen tapoja yhteistyössä käytännön toimijoiden kanssa. Tällöin opiskelijat ovat pystyneet rikastuttamaan käytännön suunnittelu- ja kehittämisorganisaatioiden toimintaa samalla tavoin kuin täydennyskoulutusopiskelijat, joiden oppiminen ei ole pelkästään henkilökohtaista oppimista vaan parhaassa tapauksessa organisaatioiden oppimista (Mattila \& Mynttinen 2011; Mattila ym. 2012). Kaupungissa toimijoiden kenttä on moninainen ja kerrostunut. Se sisältää sekä yksilötoimijoita että organisaatioita, mikä tekee kaupungista erityisen haasteellisen yhteistyöympäristön. Kokonaisuuksien hahmottaminen kaupunkien kehittämisessä edellyttää laajaa kirjoa erilaisia asiantuntijuuden muotoja.

\section{OSAAMISPERUSTAISUUS JA TYÖELÄMÄTAIDOT YLIOPISTO-OPETUKSESSA}

Yliopistossa tutkintojen ja opetuksen suunnittelun keskiössä on perinteisesti ollut sisältöosaamisen näkökulma. Sisältöosaamisessa korostuu tieto, mikä on korkeakoulukontekstissa ymmärrettävää - onhan yliopistoa aina pidetty tiedon kehtona. Nyky-yhteiskunnassa tiedon määrä on kuitenkin valtava, sen lähteet ovat moninaiset, ja tieto uusiutuu nopeasti. (Mäkinen \& Annala 2012, 128.) 


\section{TYÖEL ̈̈M̈̈TAIDOT}

KATTAVAT AJATTELUMME

MUKAAN SEK ̈̈ GENEERISET

TAIDOT ETT ̈̈ TIETEENALAN

ASIANTUNTIJUUTEEN

LIITTYV ̈̈T TYÖEL ÄM ̈̈TAIDOT.

Korkeakoulutettujen osaamista onkin alettu tarkastella aiempaa laajemmasta näkökulmasta, ja yliopistoissa on siirrytty 2000-luvulla painottamaan osaamisperustaisia tutkintoja (Bergsmann ym. 2015; Biggs \& Tang 2011; Koenen ym. 2015; Mäkinen \& Annala 2012). 'Osaamisperustaisuudella' tarkoitetaan sitä, että tutkintoja ja opetusta suunniteltaessa ja opetusta toteutettaessa keskiössä eivät ole vain opetussisällöt vaan erilaiset ja eritasoiset osaamistavoitteet, opiskelijoiden oppiminen ja oppimistulokset (osaamisen käsitteistä ks. Bergsmann ym. 2015; Mäkinen \& Annala 2012). On myös ymmärretty, että pelkkä tietoon perustuva osaaminen ei riitä, jos pyritään tarjoamaan korkeakoulututkintoja ja -opetusta, jotka tukevat riittävästi muuttuvassa yhteiskunnassa ja tulevaisuuden työelämässä tarvittavien taitojen kehittymistä (Kullaslahti \& Yli-Kauppila 2014; Räty ym. 2018; Tomlinson 2008; Tuononen ym. 2019; Ursin \& Hyytinen 2010; Vaatstra \& de Vries 2007; Virtanen \& Tynjälä 2013).

'Geneerisillä taidoilla' viitataan yleensä tieteenalasta riippumattomiin yleisiin taitoihin (Barrie 2006; de la Harpe ym. 2000; Jääskelä ym. 2018), ja Suomessa käytetään usein myös käsitteitä yleiset työelämätaidot tai siirrettävät taidot (Ursin \& Hyytinen 2010). Geneerisiin taitoihin luetaan esimerkiksi seuraavia taitoja: kriittinen ajattelu, analyyttinen päättelykyky, ongelmanratkaisutaidot ja kommunikaatiotaito sekä myös tiimityötaidot, medialukutaito, elinikäinen oppiminen ja kyky tulkita kirjallista tai matemaattista aineistoa (Ursin \& Hyytinen 2010, 67).

Geneeristen taitojen luokittelun laajuus vaihtelee tutkimuksissa muutamasta osaamisalueesta jopa noin 80 taidon luetteloihin (Tymon 2013; Ursin \& Hyytinen 2010; ks. myös Barrie 2006; Jones 2009; Pitman \& Broomhall 2009; Virtanen \& Tynjälä 2013). Luokittelujen eroavuuksia selittävät osin merkityserot käytetyissä käsitteissä. Vaikka geneeriset taidot ja yleiset työelämätaidot tai siirrettävät taidot usein rinnastetaan, niitä käytetään tutkimuksissa myös hiukan eri merkityksissä (Ursin \& Hyytinen 2010, 67).

Työelämätaitoihin paneutuneet Anne Virtanen ja Päivi Tynjälä (2013) käyttävät geneeristen taitojen sijaan käsitettä työelämätaidot tai yleiset työelämätaidot ja perustelevat termivalintaansa sillä, että he kartoittavat myös tiettyihin aloihin tai ammatteihin liittyviä taitoja eivätkä keskity alasta riippumattomiin geneerisiin taitoihin. Me puhumme yksinomaan työelämätaidoista, ja ne kattavat ajattelumme mukaan sekä geneeriset taidot että tieteenalan asiantuntijuuteen liittyvät työelämätaidot, vaikka tunnistammekin eron niiden välillä.

Virtanen ja Tynjälä (2018) käyttävät toisessa tutkimuksessaan taitojen jaottelussa Marilyn Binkleyn ja tutkijaryhmän (2012) mallia ja keskittyvät erityisesti ajattelun taitoihin. Mallin taustalla on ajatus tulevaisuuden taidoista eli niin sanotuista 2000-luvun taidoista, joita ovat muun muassa kriittinen ajattelu ja ongelmanratkaisu, oppimaan oppiminen ja metakognitiiviset taidot sekä kommunikaatio- ja yhteistyötaidot. Nämä ovat laajaalaisia, oppiaineesta tai tieteenalasta riippumattomia taitoja, joiden on nähty olevan tärkeitä osana tulevaisuuden kansalaisuutta (Norrena 2013), ja niiden voidaankin nähdä yhdistyvän ajatteluun geneerisistä tai työelämätaidoista.

Myös me tukeudumme Binkleyn ja tutkijaryhmän (2012) jaotteluun, ja tarkastelemme opiskelijoiden kokemuksia neljän eri tavoin painottuvan työelämätaitojen ryhmän näkökulmasta, joita ovat

1) ajattelun taidot: luovuus ja innovaatio; kriittinen ajattelu, ongelmanratkaisu, päätöksenteko, oppimaan oppiminen tai metakognitiiviset taidot (ways of thinking)

2) työskentelyn taidot: muun muassa vuorovaikutus ja yhteistyö (ways of working) 
3) työskentelyn työkalut: muun muassa informaatiolukutaito, tiedonhakutaidot ja digitaaliset taidot (tools for working)

4) taito toimia kansalaisena maailmassa: muun muassa aktiivinen kansalaisuus, urasuunnittelu sekä henkilökohtainen ja sosiaalinen vastuu (ways of living in the world). ${ }^{1}$

Työelämätaidot eivät ole aina tieteenalasta riippumattomia tai irrallaan asiantuntijuuden osa-alueista (ks. myös Nykänen \& Tynjälä 2012; Jääskelä ym. 2018), sillä korkeakoulutettujen asiantuntijoiden osaamisessa esimerkiksi kriittinen ajattelu ja ongelmanratkaisu kytkeytyvät tiiviisti tieteenalaosaamiseen ja tietyn alan substanssi- eli sisältöosaamiseen (ks. myös Biggs \& Tang 2011). Asiantuntijuuden on puolestaan katsottu koostuvan teoreettisesta käsitteellisestä osaamisesta, käytännöllisestä soveltavasta osaamisesta, itsesäätelyyn liittyvästä osaamisesta sekä sosiokulttuurisesta osaamisesta (ks. esim. Virtanen \& Tynjälä 2018, 3). Binkleyn ja tutkijaryhmän (2012) jaottelussa tämän eron voi karkeasti tulkita siten, että kategoriat 1) ja 4) nivoutuvat myös omaan tieteenalaan ja edustavat näin tieteenalaan kytköksissä olevia työelämätaitoja, kun kategorioissa 2) ja 3) painotus on geneerisissä taidoissa.

\section{OPETUSMENETELMIEN JA PEDAGOGISTEN KÄYTÄNTEIDEN VAIKUTUS TYÖELÄMÄTAITOJEN OPPIMISEEN}

Tutkimusten (ks. esim. Tuononen ym. 2019) ja yliopistojen uraselvitysten (Kurlin ym. 2018) perusteella korkeakouluopetuksen on todettu tukevan oman alan teoreettisen osaamisen kasvua, analyyttisen, systemaattisen ajattelun sekä tiedonhankintataitojen kehittymistä ja kykyä oppia uutta. Työelämässä tarvittavista osaamisalueista heikommin näyttäisivät kehittyvän yhteistyötaidot, stressinsietokyky, organisointi- ja koordinointitaidot, neuvottelutaidot, verkostoitumistaidot ja projektinhallintataidot. Lisäksi yliopisto-opintojen on todettu kehittävän hyvin kriittistä ajattelua ja vieraan kielen taitoja ja vastaavasti taas huonommin suunnittelutaitoja, vastuunoton, päätöksenteon ja ajanhallinnan taitoja sekä ongelmanratkaisutaitoja (García-Aracil \& van der Velden 2008; Teichler 2007). Tutkimukset ovat siis osoittaneet, että yliopisto-opinnot eivät anna valmistuneille riittävästi työelämässä tarvittavia taitoja (Jääskelä ym. 2018).

Työelämätaitoja on yliopistoissa alettu kehittää muun muassa projektikurssien avulla. Projektioppimisessa (Grant 2011; Helle ym. 2006; Jääskelä ym. 2018; Krajcik \& Namsoo 2014) lähtökohtana ovat opiskelijoiden ja usein ulkopuolisen yhteistyökumppanin kehittämisintresseistä nousevat kysymykset tai ongelmat, joihin opiskelijat kehittävät ratkaisuja. Projektit tähtäävät konkreettiseen lopputuotokseen, jossa selvitettävänä ollut kysymys tai ongelma pyritään ratkaisemaan. Projektioppiminen innostaa opiskelijoita kysymään, etsimään tietoa, ideoimaan, suunnittelemaan ja testaamaan erilaisia vaihtoehtoja. (Koh ym. 2010.) Työskentely pohjaa jaettuun asiantuntijuuteen ja tutkivaan oppimiseen (Lonka 2015).

Projektipohjainen oppiminen luo aktivoivan oppimisympäristön, jossa opiskelijat saavat kokemuksia itsenäisestä oppimisesta, yhteistyöstä ja ryhmässä toimimisesta, ongelmien systemaattisesta työstämisestä, teoreettisen tiedon soveltamisesta käytäntöön ja todellisten ongelmien ja tapausten ratkaisusta sekä projektin hallinnasta (Vaatstra \& de Vries 2007; Jääskelä ym. 2018).

Projektikurssien toteutuksessa voidaan hyödyntää ilmiöpohjaista oppimista. Se on määritelty oppimiseksi, jonka lähtökohtana toimivat todellisen maailman ilmiöt ja jossa ilmiöihin liittyviä tietoja ja taitoja opetellaan tieteenalarajat ylittäen (Lonka ym. 2015). Ilmiöpohjaisuuden myötä yliopistoopetuksessa on alettu kiinnittää huomiota erityisesti monimutkaisten ja niin sanottujen ilkeiden ongelmien - ongelmien, joille ei ole oikeaa ja pysyvää ratkaisua eikä ratkaisumetodia - ymmärtämiseen ja ratkaisemiseen (ks. Cantor ym. 2015). Kurssisarjamme aiheen, kaupunkikehittämisen, alalla lähes kaikkien ongelmien on väitetty olevan ilkeitä ongelmia (Rittel \& Webber 1973). Tällaisten ongelmien ja ilmiöiden kanssa työskentely vaatii monialaisuuden ja tieteidenvälisyyden hyödyntämistä opetuksessa (Jacob 2015; Klaassen 2018; Mikkeli \& Pakkasvirta 2007). 


\section{YHTEISTYÖT̈̈ JA}

\section{VUOROVAIKUTUSTA}

\section{HYÖDYNT ̈̈V̈̈T K ̈̈YT ÄNTEET}

\section{JA KONSTRUKTIIVISEN}

\section{OPPIMISYMPÄRISTÖN PIIRTEET}

\author{
TUKIVAT GENEERISTEN
}

TAITOJEN OPPIMISTA.

Viittaamme monialaisuudella monen eri tieteenalan läsnäoloon opetuksessa, kun taas tieteidenvälisyys ulottuu yli perinteisten tieteenalarajojen ja rajoja kyseenalaistavaan tutkimiseen ja oppimiseen (esim. Mikkeli \& Pakkasvirta 2007, 65). Siinä missä monialaisuus ei vielä yleensä tuota opiskelijoille ongelmia, tieteidenvälisen ajattelun oppiminen ja hyödyntäminen on usein heille hankalaa (Spelt ym. 2009). Tutkimukset eivät myöskään ole antaneet selkeää vastausta siihen, miten ja miltä osin heterogeenisissa ja monialaisissa ryhmissä työskentely tukee oppimista. Siitä on näyttöä, että heterogeenisuudella, erityisesti demografisilla tekijöillä, on myönteistä vaikutusta ryhmän työskentelyn laatuun (Curşeu ym. 2018; Pluut \& Curşeu 2013; Popov ym. 2012).

Yleisesti myös uskotaan heterogeenisten ryhmien olevan homogeenisempiä ryhmiä luovempia päätöksenteossa ja saavuttavan parempia ratkaisuja. Homogeenisten ryhmien on kuitenkin todettu ratkaisevan ongelmia nopeammin kuin heterogeenisten (Curşeu ym. 2007.) Lisäksi monialaisen ja tieteidenväliseen ajatteluun pyrkivän ryhmätyöskentelyn edellyttämien neuvottelutilanteiden on todettu edistävän oppimista sekä opiskelijan omien aiemmin opittujen tietojen aktivoitumisen että vertaisilta saadun uuden tiedon kautta. (Lattuca ym. 2004; Lonka ym. 2015.)

On tuotu esiin, että tarvitaan lisätutkimusta siitä, millaista osaamista yliopisto-opetuksessa käytettävät opetusmenetelmät kehittävät (Virtanen \& Tynjälä 2018). Vaikka opiskelijakeskeisen opetuksen tärkeyttä on korostettu, tutkimustulokset ovat osin ristiriitaisia sen suhteen, kuinka hyvin opiskelijakeskeiset oppimis- ympäristöt tukevat syväsuuntautunutta opiskelua ja laadukkaita oppimistuloksia. Oppimisympäristön osatekijät, opetusmenetelmät mukaan lukien, voivat vaikuttaa opiskelijoiden oppimiseen myönteisesti etenkin silloin, kun opettaja rohkaisee opiskelijoita vuorovaikutukseen. Jotkut opiskelijat näyttävät silti olevan immuuneja oppimisympäristölle. (Uiboleht ym. 2018, 2019.)

Projektioppimisen on todettu kehittävän monenlaisia työelämätaitoja (esim. Jääskelä ym. 2018; Vesterinen 2001). Riina Vaatstra ja Robert de Vries (2007) ovat tutkineet yhtäältä ongelmalähtöisen oppimisen ja projektipohjaisen oppimisen sekä toisaalta opettajajohtoisen opetuksen eroja osaamisen kehittymisen kannalta. Heidän tutkimuksensa osoittaa, että oppimisympäristön muodolla on vaikutusta erityisesti niin sanottujen yleisten tai työelämätaitojen omaksumiseen (ks. myös Patria 2014; Vermeulen \& Schmidt 2008; Virtanen \& Tynjälä 2018).

Ongelmalähtöisen oppimisen on todettu vaikuttavan merkittävästi seitsemän taidon kehittymiseen: 1) tieteidenvälinen ajattelu, 2) oppialakohtainen tieto ja sen menetelmät, 3) suunnittelu ja organisointi, 4) ongelmanratkaisukyky, 5) reflektoiva ajattelu, 6) itsenäinen työskentely ja 7) ryhmätyöskentely. Sen sijaan opettajajohtoinen opetus ei kehitä näitä taitoja. Ongelma- ja projektilähtöisiä menetelmiä opinnoissaan hyödyntämään päässeillä opiskelijoilla onkin oman kokemuksensa mukaan geneerisiä ja reflektoivia taitoja enemmän kuin niillä opiskelijoilla, jotka ovat olleet opinnoissaan perinteisempien menetelmien parissa. (Vaatstra \& de Vries 2007, 344.)

Virtanen ja Tynjälä (2018) ovat tutkineet erilaisten pedagogisten käytänteiden vaikutusta työelämätaitojen oppimiseen ja keskittyneet erityisesti luovuuden, ajattelun taitojen ja elinikäisen oppimisen tarkasteluun. Heidän mukaansa mikään yksittäinen menetelmä ei ollut edellytys näiden taitojen oppimiselle, mutta erilaiset yhteistyötä ja vuorovaikutusta hyödyntävät käytänteet sekä konstruktiivisen oppimisympäristön piirteet tukivat geneeristen taitojen oppimista paremmin kuin perinteisemmät yliopisto-opetuksen muodot, esimerkiksi luennointi ja lukeminen. Yksittäisistä ajattelun taidoista tarvitaan kriittisen ajattelun taitojen osalta Virtasen ja Tynjälän 


\section{TARKASTELTAVAA KOHDETTA}

\section{ON LUONTEVAA KUVATA}

\author{
MONIALAISEKSI ILMIÖKSI.
}

(2018) mukaan lisätutkimusta, jotta ymmärretään yhä paremmin pedagogisten käytänteiden vaikutus kriittisen ajattelun oppimiseen. Kriittisen ajattelun taitojen kehittymistä yliopisto-opintojen aikana on kyllä tutkittu (ks. Hyytinen 2015), mutta vielä ei ole riittävästi tietoa pedagogisten käytänteiden vaikutuksesta tähän osaamisalueeseen.

\section{KAUPUNKI YLIOPISTOPEDAGOGISENA KENTTÄNÄ}

"Suunniteltu ja koettu kaupunki" on Helsingin yliopiston ja Aalto-yliopiston yhteistyönä järjestämä kurssisarja, jonka tavoitteena on tuottaa opiskelijoille kykyjä rakentaa vuoropuhelua koetun kaupungin, historiallisten tietolähteiden sekä tulevaisuuden suunnitellun kaupungin välille. Kurssin opettajat ovat edustaneet humanistisia tieteitä ja rakennetun ympäristön asiantuntijuutta maankäytön, kiinteistötalouden ja liikennetekniikan aloilta ja opiskelijat puolestaan laaja-alaisesti kaupunkitutkimuksen, -kehittämisen ja -suunnittelun eri tieteenaloja.

Kolmena lukuvuonna järjestetyllä "Suunniteltu ja koettu kaupunki" -kurssilla on ollut tavoitteena tarkastella kokeellisesti, miten paikkaan liittyviä ajallisia kerrostumia ja niihin kytkeytyviä kokemuksia voitaisiin sisällyttää kaupunkisuunnitteluun ja -kehittämiseen, jota usein hallitsevat tekniset, taloudelliset ja hallinnolliset näkökulmat. Samalla on pyritty saamaan opiskelijoita pohtimaan kaupunkitutkimuksen osallistavaa roolia kaupunkien kehittämisessä eli selvittämään, miten tutkimuksen kautta voitaisiin saada kaupunkilaisia aiempaa laajemmin vaikuttamaan oman ympäristönsä kehittämiseen. Käytännössä tämä on tarkoittanut esimerkiksi erilaisten tiedon tuottamisen muotojen testaamista osana suunnitteluprosessia. Tarkasteltavaa kohdetta on siis luontevaa kuvata monialaiseksi ilmiöksi, jossa tieteelliset teoriat ja lähestymistavat kohtaavat arjen kaupunkisuunnittelun ja -kehittämisen konkreettisia kysymyksiä.

Kursseilla on työskennelty monialaisissa pienryhmissä käytännön kaupunkisuunnittelun ja -kehittämisen kysymysten parissa. Työskentelyä ovat tukeneet ja ohjanneet kaupunkikehittämisessä mukana olevat toimijat sekä kunkin kurssin aihepiiriin johdattelevat asiantuntijaluennot.

Ensimmäisen kerran kurssi järjestettiin syksyllä 2016, jolloin kohteena oli Helsingin Merihaka ja yhteistyökumppanina Helsingin kaupunki. Tätä kurssia emme tarkastele tässä tutkimuksessa, koska emme kurssin aikana pyytäneet opiskelijoilta tutkimuslupaa. Syksyllä 2017 kohteeksi valittiin Helsingin Hakaniemi ja yhteistyökumppaniksi kiinteistösijoitusyhtiö Antilooppi. Tälläkin kurssilla oli mukana Helsingin kaupungin asiantuntijoita: kaupunkisuunnittelun lisäksi myös elinkeinotoiminnan puolelta. Kolmannen kurssin teemana oli mobiliteetti ja yhteistyökumppanina Helsingin seudun liikenne -kuntayhtymä (HSL). Tämä kaupunkilaisten liikkumista ja liikkumisvalintoja tarkastellut kurssi järjestettiin keväällä 2019.

Vaikka kurssisarjan pääsisältö on pysynyt samana, kunkin kurssin osaamistavoitteiden asettamisessa huomioitiin kurssin teema ja kohde. Ensisijaisena tavoitteena on ollut oppia hahmottamaan kaupungin muutosprosesseihin vaikuttavia tekijöitä ja vaikuttamaan prosesseihin tieteidenvälisen työskentelyn tuottaman ymmärryksen pohjalta. Lisäksi olemme nostaneet esiin muutosprosesseihin liittyvät mielikuvat ja niiden muodostumisen ymmärtämisen.

Hakaniemen alueeseen keskittyvällä kurssilla syksyllä 2017 painopiste oli alueen rakennuksissa ja niiden suhteessa ympäristöön. Kurssilla korostuivat kaupunkikehittämisen monet toimijat, ja tärkeä tavoite oli oppia tuntemaan toimijaryhmien merkitys kaupunkiympäristön muotoutumisessa sekä hahmottamaan näiden toimijaryhmien välisiä vaikutussuhteita. Kevään 2019 mobiliteetti-kurssilla tavoitteena oli hahmottaa kaupunkilaisten liikkumiseen, sen muutokseen ja tulevaisuuden kehitykseen vaikuttavia tekijöitä sekä vastata ja vaikuttaa kaupunkilaisten liikkumiseen liittyviin tarpeisiin omalla ehdotuksellaan. Opiskelijaryhmät laativat omasta 


\section{TYÖELÄMÄTAIDOT KEHITTYIVÄT} OPISKELIJOIDEN MUKAAN

\section{KURSSEILLA MONIPUOLISESTI.}

kehittämisehdotuksestaan visuaalisen PowerPointesityksen ja suullisen esityksen, joita työstettiin harjoittelun ja palautteiden avulla kurssin aikana. Lisäksi ryhmät tuottivat loppuraportin.

\section{AINEISTO JA SEN ANALYYSI}

Aineistona käytämme Hakaniemi- ja mobiliteettikurssin materiaaleja, joista pääosan muodostavat opiskelijoiden vastaukset kurssikyselyihin. Toisen kurssin osalta hyödynnämme myös ryhmätöinä laadittuja loppuraportteja. Kaikkeen käyttämäämme aineistoon on saatu opiskelijoilta tutkimuslupa. Artikkelissa esiin tulevia kommentteja ei ole yksilöity kehenkään yksittäiseen opiskelijaan, vaan niihin viitataan kurssikohtaisesti. Opiskelijoille suunnatut kyselyt koostuivat avokysymyksistä, ja lomakkeet laadimme niin, että ne mahdollistivat myös laajempaa kuvailua. Vastaamiseen varattiin aikaa luentojen yhteydestä.

Kyselyt tuovat esiin opiskelijoiden yksilöllisiä, henkilökohtaisia kokemuksia, joissa vastaukset on muodostettu suhteellisen lyhyen pohdinnan perusteella. Tästä huolimatta vastaukset ovat pääasiassa pohdiskelevia ja reflektoivia mutta samalla varsin kiteytyneitä, toisinaan luettelomaisiakin analyyseja omasta oppimisesta. Laajuudeltaan vastaukset kuhunkin kysymykseen ovat muutamia rivejä. Loppuraportit tarjosivat toisenlaisen mahdollisuuden oman oppimisen pohdintaan, sillä ne edustavat opiskelijaryhmien yhteisesti kurssin kuluessa muodostamia näkemyksiä. Oppimisen prosessointiin oli siis enemmän aikaa. Näin analyysit ovat kyselyvastauksia monisanaisempia ja edustavat ryhmän sisäistä konsensusta.

Toisen kurssin päätteeksi järjestettiin loppukeskustelu, jotta opettajilla olisi mahdollisuus tarkentaviin kysymyksiin ja opiskelijoilla tilaisuus nyansoida kuvauksiaan oppimisesta. Keskustelu kesti noin 90 minuuttia, ja siinä oppimiskokemuksen moniäänisyys korostui, kenties yllättäenkin, suhteessa muihin aineistoihin. Yhteinen keskustelu nosti esiin argumentteja ja vasta-argumentteja ryhmäkohtaisiin kokemuksiin perustuen. Monet kokemukset olivat kurssin opiskelijoiden yhteisesti jakamia, mutta keskustelu toi esiin myös ryhmäkohtaisia eroja.

Syksyn 2017 Hakaniemi-kurssilla kyselyt koottiin kirjallisesti. Kurssin alussa opiskelijat antoivat anonyymisti vastaukset kyselyyn, jossa tiedusteltiin muun muassa aiempaa kokemusta monitieteisistä tai tieteidenvälisistä projekteista ja yliopiston ulkopuolisten toimijoiden kanssa yhteistyössä toimimisesta. Alkukyselyn vastauksia emme tuo esiin analyysissa, mutta ne toimivat lähtökohtina kurssin muodon ja sisällön viimeistelylle sekä palautekyselylle. Alkukyselyn tarkoituksena oli myös ohjata opiskelijoita reflektoimaan kurssin aikana omaa oppimistaan etenkin työelämätaitojen saralla.

Kurssin lopulla tehtyyn palautekyselyyn saatiin 10 vastausta. Kysymyksiä oli seitsemän, ja niissä kysyttiin monitieteisyyden ilmenemisestä kurssilla, tieteidenvälisen työskentelyn mahdollisesta haastavuudesta ja uusien näkökulmien soveltamiseen saadusta tuesta, vuorovaikutuksesta ja yhteistyöstä eri taustoista tulevien opiskelijoiden kesken, yhteistyöstä yhteistyökumppanien kanssa, kurssilla kehittyneistä työelämätaidoista, ryhmän projektityöstä oppimisprosessina sekä toiveista kurssin jatkokehittelyä koskien.

Kevään 2019 mobiliteetti-kurssilla koottiin palautekysely, joka niin ikään kerättiin kirjallisesti ja anonyymisti. Kurssin loppukeskustelu koottiin puolestaan suullisena ryhmäkeskusteluna kurssin viimeisellä kerralla. Läsnä oli kuusi opiskelijaa, ja loppukeskustelu äänitallennettiin. Keskustelu käytiin vapaamuotoisesti, mutta opiskelijoille annettiin hetki aikaa ennen keskustelua pohtia omia näkökulmiaan oppimisesta kurssilla, vuorovaikutuksesta ja yhteistyöstä eri taustoista tulevien opiskelijoiden kanssa sekä ryhmätyöprosessista. Erikseen nostettiin esille kurssilla mahdollisesti saavutetut työelämätaidot ja yhteistyö HSL:n kanssa sekä sen merkitys oppimiselle.

Lisäksi käytämme aineistona opiskelijaryhmien loppuraportteja Hakaniemi-kurssilta. Raportteja on yhteensä neljä, ja kunkin laajuus on noin seitsemän 


\begin{tabular}{|l|l|l|}
\hline Puhetavat & Hakaniemi & Mobiliteetti \\
\hline Palautekysely & 10 & 8 \\
\hline Loppuraportti & 4 & \\
\hline Loppukeskustelu & & 1 \\
\hline
\end{tabular}

Taulukko 1. Analyysissa hyödynnetyn aineiston koostuminen kurssikohtaisesti.

sivua. Ryhmätöinä laadituissa raporteissa on tuotu esiin aiheenvalintaan johtaneita tekijöitä, kuvattu teoreettisia ja metodologisia näkökulmia sekä aineiston kartoittamista, tarkasteltu soveltavia mahdollisuuksia sekä kuvattu ryhmätyöskentelyä ja sen onnistumista. Kaikki aineisto (taulukko 1) on kirjoittajien hallussa, ja sitä säilytetään kaksi vuotta aineiston kokoamisen jälkeen.

Aineiston analyysissa on hyödynnetty teoriaohjaavaa sisällönanalyysiä. Aineisto on tulkinnan keskeinen lähtökohta, vaikka operointi teoreettisilla käsitteillä ohjaakin analyysia. (Tuomi \& Sarajärvi 2009.) Oman aineistomme kohdalla tämä on tarkoittanut teoriaohjaavuutta osin jo aineistoa tuottaessamme, mikä näkyy ennen kaikkea kurssien opiskelijoille suunnatuissa kyselyissä. Aineiston luennassa olemme nojautuneet Binkleyn ja tutkijaryhmän (2012) nelijakoon työelämätaidoista. Ensimmäiset aineiston lukukerrat teimme kuitenkin ilman tietoista kiinnittymistä mihinkään valmiisiin kategorioihin pyrkien hahmottamaan yleisesti yhtäältä opiskelijoiden myönteisiä kokemuksia kursseista ja toisaalta heidän esittämiään epävarmuuksia tai kriittisiä huomioita kurssista ja sen suorittamisesta. Etsimme aineistosta ne kohdat, jotka liittyivät jollakin tavoin siihen, millaista osaamista opiskelijat tarvitsivat ja mitä he kokivat oppineensa kurssin aikana.

Ensimmäisten lukukertojen jälkeen kiinnitimme huomiomme nelikentän eri osa-alueita heijastaviin kommentteihin. Kyselyissä eri taitoja ei ollut listattu edes esimerkinomaisesti. Näin opiskelijoiden analyysit omista toiveistaan ja oppimisprosessistaan ovat heidän itsensä "sanoittamia".

\section{TULOKSET}

Työelämätaidot kehittyivät opiskelijoiden mukaan kursseilla monipuolisesti. Lisäksi he toivat esiin kokemuksiaan monialaisesta ja tieteidenvälisestä työskentelystä suhteessa oman alan asiantuntijuuteen.

\section{Kurssien aikana kehittyneet työelämätaidot}

Opiskelijoiden kokemusten perusteella kurssit valmistivat heitä hyvin työelämään. He toivat pohdinnoissaan esiin monia työelämätaitoja, jotka kehittyivät kurssin aikana. Nämä ovat yhteneväisiä projektikursseilla oppimista tarkastelleen Joyce Hwee Ling Kohin ja tutkijaryhmän (2010) sekä Vaatstran ja de Vriesin (2007) tutkimusten tulosten kanssa. Kun kurssilla kehittyneitä työelämätaitoja tarkastellaan Binkleyn ja tutkijaryhmän (2012) esittämän jaottelun näkökulmasta, voidaan erilaisia taitoja hahmottaa nelikentän jokaiselta osa-alueelta (taulukko 2). Toisinaan jotkin taidot yhdistyvät jaottelun useammalle alueelle sisältämiensä erilaisten ulottuvuuksien vuoksi. Selkeimmin opiskelijoiden kommentit painottuivat työskentelyn taitoihin

\begin{tabular}{|c|c|c|c|}
\hline Ajattelun taidot & Työskentelyn taidot & Työskentelyn työkalut & $\begin{array}{l}\text { Taito toimia kansalaisena } \\
\text { maailmassa }\end{array}$ \\
\hline $\begin{array}{l}\text { - Kehittämistaidot ja luo- } \\
\text { van ideoinnin taidot } \\
\text { - Kyky soveltaa tietoa käy- } \\
\text { täntöön } \\
\text { - Kriittinen ajattelu }\end{array}$ & $\begin{array}{l}\text { - Ryhmätyötaidot } \\
\text { - Yleiset vuorovaikutus- } \\
\text { taidot } \\
\text { - Projektityöskentelyn ja } \\
\text { projektinhallinnan taidot } \\
\text { - Ajanhallintataidot ja } \\
\text { stressinsietokyky² } \\
\text { - Suunnittelutaidot } \\
\text { - Esiintymistaidot }\end{array}$ & $\begin{array}{l}\text { - Tiedonhaun taidot } \\
\text { - Kyky hyödyntää erilaisia } \\
\text { menetelmiä (ml. erilaiset } \\
\text { digitaaliset välineet) } \\
\text { - Esiintymistaidot (esittä- } \\
\text { mistekniikan käyttö) }\end{array}$ & $\begin{array}{l}\text { - Vuorovaikutustaidot eri- } \\
\text { laisten toimijoiden kanssa } \\
\text { ja monialaisissa ryhmissä } \\
\text { - Oman asiantuntijuuden } \\
\text { tunnistaminen }\end{array}$ \\
\hline
\end{tabular}

Taulukko 2. Opiskelijoiden esille nostamat kurssin aikana kehittyneet työelämätaidot. 


\section{LUOTTAMUS OMIIN TAITOIHIN ON TÄRKË̈ LÄHTÖKOHTA}

ONNISTUNEELLE VUORO-

VAIKUTUKSELLE TYÖELÄM $\ddot{A S S A ̈ . ~}$

ja työkaluihin. Projektityöskentely- ja erilaisia vuorovaikutustaitoja tuotiin esiin laajalti.

Opiskelijoiden esille nostamat työelämätaidot ovat pitkälti taitoja, joissa uraseurantatulokset (Kurlin ym. 2018; Tuononen ym. 2019) ja kansainväliset tutkimukset (García-Aracil \& van der Velden 2008; Teichler 2007) ovat osoittaneet olevan puutteita yliopistosta valmistuneilla. Kurssilaiset saivat mielestään lisää osaamista erityisesti työskentelyn taitoihin kuuluvien taitojen alueilla (esimerkit 1,2 ja 3). Alla olevissa esimerkeissä mainitaan lisäksi muun muassa ajattelun taidoista kehittämistaidot sekä kyky luovaan ideointiin.

(1) Kurssi toimi mielestäni hyvin työelämään valmistavasti. Sain erilaisia projektityö- ja suunnittelukokemusta sekä ryhmätyökokemusta. $\left(\mathrm{H}^{3}\right)$

(2) Projektinhallintataitoja, esiintymistaitoja, esityksen tekemisen taitoja, ihan teknisestikin. Suunnittelutaitoja, kehittämistaitoja, luovaa ideointia. $(\mathrm{H})$

(3) Kurssin aikana kukin oppi projektinhallintaa käytännössä. Eli sitä miten aikataulutetaan töitä ja miten kokoustetaan ja sovitaan asioita muiden kanssa. Tämän lisäksi hyödyllistä oli nimenomaan suunnittelutyö ja kehittelytyö. Se oli myös haastavinta moneltakin kannalta, mutta samalla juuri sitä, mistä on varmasti hyötyä työelämää silmällä pitäen. ( $\mathrm{H}$ lr)

Esimerkit suhteuttavat oppimiselle asetettuja tavoitteita ja heijastavat opiskelijoiden ymmärrystä siitä, että työelämätaitojen omaksuminen ei voi pohjautua yksittäisiin kursseihin vaan taidot ovat kumuloituvia ja perustuvat kokemuksiin. Esimerkissä 2 korostuu lisäksi työelämätaitojen käytännönläheisyys, mitä ei tulisi yliopisto-opetuksessa sivuuttaa itsestäänselvyytenä (ks. myös esimerkki 4). Mobiliteetti-kurssilla laaditut ryhmätyöt esiteltiin Kaupunkitutkimuksen päivillä, joten esiintymistekniikka korostui. Opiskelijat pitivät esitysten harjoittelua ja kehittämistä saadun palautteen pohjalta tärkeänä. Ryhmäläiset kokivat oppineensa myös toisten ryhmien esityksistä ja niiden saamista kommenteista. (M lk.)

Opiskelijat mainitsivat pohdinnoissaan usein vuorovaikutukseen ja ryhmätyöskentelyn taidot. Luottamus omiin taitoihin niin esitystekniikassa kuin -taidoissa on tärkeä lähtökohta onnistuneelle vuorovaikutukselle työelämässä. Opiskelijat korostivat, että kurssin ansiosta heidän ryhmätyötaitonsa ja taitonsa työskennellä monialaisissa tiimeissä kehittyivät (esimerkit 4 ja 5). He oppivat myös kommunikoimaan eri toimijoiden kanssa (esimerkit 6 ja 7). Oman osaamisen tunnistaminen tulee esiin (esimerkki 7). Näitä kaikkia taitoja voidaan tulkita myös omaan tieteenalaan sitoutuvina työelämätaitoina.

(4) Ryhmätyötaitoja: kriittisyyttä, ideointia, keskustelemista, organisointia, toisten huomioimista, kärsivällisyyttä. Teknisiä taitoja: Google Driven hallinta, PP-esityksen luominen. (M)

(5) Ymmärrän taas hieman paremmin, miten muista taustoista tulevien ihmisten kanssa tulee työskennellä. (H)

(6) Konkreettista eri alojen välistä kommunikointia. Erilaisia tapoja kommunikoida suunniteltavan alueen asukkaiden/käyttäjien kanssa ja muistaa kuinka valtavan tärkeää se on! $(\mathrm{H})$

(7) Mitä sitten opimme prosessin aikana? Huomattavan määrän kaupunkisuunnittelusta, kiinteistösijoittamisesta ja alueiden kulttuurisesta hahmottamisesta. Prosessi oli innostava, sillä harvoin opintojen aikana pääsee visioimaan konkreettiselle alueelle ideoita, jotka oikea taho ottaa huomioon oikeaan aikaan. Opimme myös omista lähtökohdistamme ja siitä miten sovitamme yhteen erilaisia näkökantoja ja toiveita niin ryhmämme sisällä kuin kaupunkisuunnittelun näkökulmasta. Miellyttävää oli myös luoda kontakteja työelämään Antiloopin ja kaupungin työntekijöiden suuntaan. Kaupungin päätösten 


\section{Opetus SIMULOI}

\section{ITSEN $\ddot{A} I S T \ddot{A}$ TYÖELÄM $\ddot{A} N$}

\author{
RYHM ̈̈TYÖSKENTELYÄ.
}

tekijät ja päätösten logiikka avautui keskusteluissa syvemmin kuin ikinä päätösten kirjallisia versioita lukiessa. Ymmärrys, josta on varmasti hyötyä myös laajemmin tulevaisuudessa. ( $\mathrm{H}$ lr)

Tärkeänä työelämätaitona opiskelijat pitivät kykyä elää sellaisten valintojen kanssa, joita ei voi tai ehdi perinpohjaisesti tutkia ja perustella. Lisäksi esimerkit kuvastavat hyvin opiskelijoiden ymmärrystä eri taustoista tulevien toimijoiden "erikielisyydestä", minkä tulkitsemme kytkeytyvän taitoihin toimia kansalaisena maailmassa. Osasimme odottaa, että kommunikointi eri tieteenaloilta tulevien opiskelijoiden kanssa voi vaatia tottumusta ja että molemminpuolisen ymmärryksen luominen on prosessi, joka kokemuksen myötä syvenee. Lisäksi etenkin Hakaniemi-kurssi oli auttanut tunnistamaan vuorovaikutuksen merkityksen suhteessa kokemusasiantuntijoihin eli kaupunkilaisiin ja toisaalta kehittänyt opiskelijoiden vuorovaikutustaitoja erilaisten toimijoiden kanssa.

Binkleyn ja tutkijaryhmän (2012) nelikentässä vuorovaikutus- ja yhteistyötaidot ovat keskeisiä työskentelyn taitojen kategoriassa. Projektikurssiemme kontekstissa vuorovaikutustaidot näyttäytyvät kuitenkin tätä laajempana kokonaisuutena ja heijastivat samalla ajattelua koskevia työelämätaitoja sekä taitoja toimia kansalaisena maailmassa. Onnistuneen vuorovaikutuksen rakentaminen on edellyttänyt uudenlaisten, kriittistenkin ajattelutaitojen omaksumista, mikä on parhaassa tapauksessa johtanut syventyneeseen kykyyn vaikuttaa oman kurssityön aihetta laajemminkin yhteiskuntaan, tässä tapauksessa kaupunkien suunnitteluun ja kehittämiseen.

Opiskelijat työskentelivät kurssien aikana tiiviisti pienryhmissä oman projektin parissa ja kokivat tämän kehittäneen heidän ryhmätyötaitojaan. He kokivat ryhmätyöskentelyn sujuneen hyvin muun muassa siksi, että ryhmä oli itseohjautuva, kommunikaatio toimi, jokainen sai hyödyntää omia vahvuuksiaan, ja ryhmässä oli samanlaisia mielipiteitä.

Luovan ideoinnin ja monialaisen suunnittelutyön näkökulmasta samanmielisyys ei aina kuitenkaan ole pelkästään positiivinen asia. Tämä kävi ilmi esimerkiksi mobiliteetti-kurssilla yhden ryhmän kohdalla. Ryhmässä sinänsä onnistuneena pidetty työskentely oli perustunut kompromissiin, jossa osa ryhmän jäsenistä koki, etteivät he pystyneet osallistumaan työhön juuri oman alansa asiantuntijoina. Tehtävän määrittelyn aikataulu oli koettu kiireiseksi, eikä ryhmä ollut annetussa ajassa pystynyt yhdistämään eri tieteenalojen asiantuntijuuksia saman teeman alle. (M lk.)

Ryhmätyöskentelyä ei kurssien aikana erityisesti ohjattu aikatauluttamista ja väliraportointeja lukuun ottamatta. Opettajat olivat kyllä ryhmien käytössä tarvittaessa, mutta heidän puoleensa ei juuri käännytty. Näin opetus simuloi itsenäistä työelämän ryhmätyöskentelyä. Palautteen pohjalta voisi kuitenkin arvioida tarpeelliseksi ryhmätyötaitojen kehittämisen nivomisen osaksi projektikurssien opetusta. Ratkaisuksi esitettiin muun muassa ryhmätyöskentelyn perusperiaatteista muistuttamista heti kurssin alussa ( $\mathrm{Mlk}$ ).

Kurssi perustui vahvasti projektityöskentelyyn, ja opiskelijat joutuivat ottamaan vastuuta projektin etenemisestä sovitussa aikataulussa. Opiskelijoiden pohdinnoissa nousikin esiin, että kurssi auttoi heitä parantamaan ajanhallinnan ja stressinsietokyvyn taitoja (ks. esimerkki 3). Eräs opiskelija mainitsi, että "aikaa olisi toivonut enemmän eli hiukan kiireen tuntu tuli, mutta tämä oli myös oikeastaan hyvä, sillä työelämässä täytyy nopeasti kehittää / ideoida jne.” (H). Projektin aikana opiskelijat joutuivat hakemaan myös itsenäisesti tietoa ja selvittämään erilaisten menetelmien käyttöä sekä hyödyntämään niitä käytännössä. Työskentely kehitti siten tiedonhaun taitoja ja kykyä hyödyntää erilaisia menetelmiä (esimerkit 8,9 ja 10):

(8) Ns. substanssiosaaminen kaupunkitutkimukseen liittyen on osoittautunut hyödylliseksi, samoin metodologinen osaaminen. Tutkimuskysymysten asettelu ja rajaus ovat asettaneet haasteita koko tiimille, ja ylipäätään tutkimuksen tekemiseen liittyvät tiedot ovat tulleet tarpeen. (M) 


\section{Ajattelun taidoista \\ OPISKELIJAT MAINITSIVAT \\ OPPINEENSA LUOVUUTTA JA \\ KEHITTÄMISEN TAITOJA.}

(9) Kun metodit on erilaisia ja lähestymistavat on erilaisia niin vaikka on se sama aihe niin se itsessään jo se työskentely itsessään opettaa itsellekin ihan älyttömän paljon ja lisää sellaista perspektiiviä. (H) (10) Ryhmämme sovelsi useita menetelmiä. Historiallisten, kirjallisten lähteiden lisäksi käytimme PehmoGIS-menetelmillä kerättyä aineistoa onnen paikkojen visualisointiin. Jaoimme alueen toimijoille sähköistä kyselylomaketta sähköpostitse, Facebook-sivustoilla ja QR-koodilla ilmoitustauluilla. (H)

Ajattelun taidoista opiskelijat mainitsivat oppineensa luovuutta ja kehittämisen taitoja. Kriittistä ajattelua, ongelmanratkaisua, päätöksentekoa tai oppimaan oppimisen taitoja ei mainittu yhtä usein, mutta joitakin kertoja kuitenkin. Niissä vastaaja esimerkiksi sanoi tuoneensa ryhmätyöskentelyyn "kriittistä arviointia" (M). Aiemmassa tutkimuksessa on esitetty, että yliopisto-opinnot tukevat oppimaan oppimisen ja analyyttisen tai kriittisen ajattelun kasvua mutta eivät niinkään esimerkiksi päätöksenteko- tai ongelmanratkaisutaitoja (García-Aracil \& van der Velden 2008; Kurlin ym. 2018; Teichler 2007; Tuononen ym. 2019).

Vaikka vain harva opiskelija toi suoraan esiin ajattelun taitoja, on kuitenkin selvää, että he tarvitsivat näitä taitoja projektien aikana. Tämä on luettavissa esimerkiksi edellisissä kuvauksissa, joissa tuodaan esiin metodisia ratkaisuja ja niiden yhteensovittamisia, tai kun opiskelijat arvioivat hankkimaansa tietoa ja tekivät sen pohjalta erilaisia ratkaisuja ja päätöksiä projektityössään. Erilaisten menetelmien oppiminen (esimerkki 10) voidaan nähdä konkreettisimmillaan työskentelyn työkaluihin liittyvän osaamisen lisääntymisenä. Kyse ei opiskelijoiden kohdalla ollut kuitenkaan ainoastaan yksittaiisten menetelmien haltuunotosta vaan myös sen ymmärtämisestä, minkälaista tietoa eri menetelmillä yksin ja yhdessä voidaan tuottaa. "Perspektiivin" lisääntyminen (esimerkki 9) voidaankin tässä yhteydessä tulkita myös uudenlaisten näkökulmien ja ajattelun muotojen avautumisena.

\section{Monialaisuus, tieteidenvälisyys ja oman alan asiantuntijuuden kehittyminen}

Oman osaamisen tunnistaminen ja tieteidenvälinen ajattelu olivat aineistossamme vahvasti kytköksissä niin toisiinsa kuin työelämätaitoihin. Työskentely monitieteisessä ryhmässä itsessään koettiin pääasiassa antoisaksi. Vastauksissa on kommentoitu, että näin pääsi oppimaan muista tieteenaloista, ja on toivottu lisää tieteidenvälistä työskentelyä tutkintoihin. Monissa vastauksissa on tuotu esiin se, etteivät tieteidenvälisen työskentelyn taidot kehity, ellei ensin tunne oman alan luonnetta ja ominaispiirteitä. Toisaalta kehämäisesti myös oman alan ytimen hahmottaminen näyttää mahdollistuvan tai ainakin helpottuvan, kun opiskelija voi suhteuttaa omaa alaansa muihin aloihin ja tätä kautta pääsee näkemään oman alansa vahvuudet. Yksi opiskelija kiteytti asian näin: "Monitieteisyys on hyvästä, oppii puolustamaan oman alan tärkeyttä ja toisaalta näkemään muiden mahdollisuudet" $(\mathrm{H})$.

Mobiliteetti-kurssin loppukeskustelussa tuotiin kuitenkin esiin myös epävarmuuksia suhteessa tieteidenväliseen työskentelyyn. Jos tieteenalojen koettiin olevan liian kaukana toisistaan, saatettiin oman tieteenalan asiantuntijuuden esiin tuominen kokea vaikeaksi. Samoin yhteisen kiinnostuksen kohteen löytäminen saattoi tällöin olla vaikeaa. Erityisesti ryhmän suuri koko, esimerkiksi viisi henkeä, nähtiin yhteistyötä vaikeuttavana. Monialaisessa ryhmässä toimiminen ja siinä tieteidenvälisen ajattelun toteutuminen vaatiikin yhtäältä taitoa nostaa esille omia näkemyksiä ja perustella niitä sekä toisaalta kykyä nähdä oman alan asiantuntijuuden kytkös ryhmän yhteiseen teemaan. Parhaimmillaan - ja useimmiten - eri tieteenalojen asiantuntijuudet kyettiin valjastamaan yhteisen tavoitteen hyväksi. Kommenteissa tuli kuitenkin esiin näkökulma, jonka mukaan tieteidenvälinen työskentely 


\section{PARHAIMMILLAAN}

\section{ERI TIETEENALOJEN}

\section{ASIANTUNTIJUUDET KYETTIIN}

\section{VALJASTAMAAN YHTEISEN}

TAVOITTEEN HYVÄKSI.

voisi toimia paremmin, jos se olisi rajattu tiettyihin peruslähtökohdat jakaviin tieteenaloihin. ( $\mathrm{Mlk}$.)

Oman alan tuntemuksen ja tunnistamisen tarve tulee esiin myös esimerkissä 11. Tarvitaan siis oman alan asiantuntijuuden tunnistamista ja myös kykyä sen sanoittamiseen, kun toimitaan yhdessä eri alojen asiantuntijoiden kanssa.

(11) Ehkä tärkein lähdemateriaali, jonka kriittinen tarkastelu oli myös kaikista vaikeinta, oli ryhmän jäsenten omat tiedot ja taidot. Työmme pohjautui teoreettisen tiedon lisäksi vahvasti käytännön työskentelyyn, jossa jokainen pääsi hyödyntämään aiemmin oppimaansa. Samalla ryhmä hyötyi merkittävästi monitieteellisestä lähestymistavasta. ( $\mathrm{H}$ lr)

Opiskelijakommenteissa tuli esiin se, miten tietopohjainen asiantuntijuus ja monialainen tai tieteidenvälinen käytännön työskentely eroavat toisistaan. Palautteissa mainittiin esimerkiksi, että suunnittelussa tarvittava luovuus voi toisinaan toteutua paremmin, kun ei tiedä liikaa. Opiskelijat havaitsivat kuitenkin myös, ettei käytännön monialaisessa tai tieteidenvälisessä työskentelyssä edes ehdi tutkia asioita minkään alan näkökulmasta kovin syvällisesti. Tällaista epävarmuutta on vain opittava sietämään:

(12) Monitieteisyys oli toisaalta kurssin parasta antia, mutta samalla se myös teki työskentelystä haastavaa. Epävarmuus iski toisinaan, sillä välillä tuntui, ettei meillä ollut tarpeeksi syvällistä tietoa vaikkapa kaupunkitutkimuksesta tai konkreettisesta suunnittelutyöstä. Ryhmän monitieteisyys aiheutti myös haasteita teoreettisten lähestymistapojen valitsemiseen ja rajaamiseen. Lopullisessa työssä hyödynsimme kaikkien taustoja ja lähtökohtia, mutta emme valinneet yksittäistä rajattua metodologiaa, sillä se olisi välttämättä jättänyt aina osan ryhmäläisistä aiheen käsittelystä syrjään. $(\mathrm{H}$ lr)

Asiantuntijuuden ja toisaalta ajattelutaitojen yksi elementti on kyky soveltaa teoreettista osaamista käytäntöön. Opiskelijoiden kokemuksen mukaan työskentely kurssilla antoi mahdollisuuden kehittää tätä osaamisaluetta. Samalla se teki näkyviksi aiemmissa opinnoissa saavutetut tiedot ja taidot:

(13) Oli hienoa päästä tekemään käytännön projektia ja saada joku tietty paikka mitä käsittelee ja soveltaa siihen oppimaansa. $(\mathrm{H})$

Lisäksi opiskelijat kokivat palkitsevaksi tiedon siitä, että he olivat pystyneet olemaan omalta osaltaan rakentamassa yhteyttä yhtäältä käytännön suunnittelu- ja kehittämistyön ja toisaalta oman alan ulkopuolellekin laajentuvan akateemisen tutkimuksen välille (Mlk).

\section{POHDINTA}

Perustutkintokoulutuksen kentällä työelämätaitojen kehittämiseen sisältyy haasteita, jotka eivät ole yhtä ilmeisiä perinteisesti työelämätaitojen kehittämiseen keskittyneessä aikuiskasvatuksessa. Näin on erityisesti täydennyskoulutuksessa, jossa voidaan rakentaa koulutuksen sisältöjä ja muotoja sen oletuksen varaan, että opiskelijoilla on käytännön työelämässä karttuneita työelämätaitoja ja kykyä tunnistaa oman asiantuntijuutensa erityispiirteet suhteessa muunlaisiin asiantuntijuuksiin.

Aineistomme pohjalta työskentely monialaisissa, tieteidenväliseen työskentelyyn pyrkivissä opiskelijaryhmissä tarjosi perustutkinto-opiskelijoille mahdollisuuden kehittää työelämätaitojaan. Opiskelijat paneutuivat projektitöissään erilaisiin kaupunkien kehittämisen ilmiöihin sekä analysoiden niitä että vaikuttaen niihin omalla toiminnallaan, mikä vahvisti opiskelijoiden ymmärrystä omista taidoistaan. Useat opiskelijat toivat kommenteissaan esiin erityisesti työskentelyn 


\section{OlenNAINEN TYÖELÄMÄTAITO ON OPISKELIJOIDEN}

\section{MAINITSEMA ROHKEUS PUHUA}

OMAN TIETEENALANSA

ASIANTUNTIJANA.

taitojen, kuten projekti- ja ryhmätyöskentelytaitojen kehityksen (Binkley ym. 2012). Opiskelijat arvostivat mahdollisuutta koetella omaa tieteenalakohtaista asiantuntijuuttaan ja saada kokemusta työelämätaidoista turvallisessa mutta tavoitteellisessa kontekstissa (ks. Biggs \& Tang 2011).

Vuorovaikutukseen liittyvä oppi liitettiin sekin vahvasti nimenomaan monialaisuuteen ja tieteidenväliseen työskentelyyn mutta myös työskentelyyn erilaisten kontaktiryhmien kanssa. Jälkimmäisellä viitattiin tarpeeseen kyetä ilmaisemaan itseään tilannesidonnaisesti erilaisille yleisöille. Ryhmien sisällä eri alojen erilaiset kommunikaatiotavat tunnistettiin, ja ryhmässä oli opittu "kääntämään" omaa osaamistaan muille ryhmäläisille samalla vahvistaen käsitystä omasta tieteenalakohtaisesta asiantuntijuudesta (heterogeenisten ja homogeenisten ryhmien eroista ks. Curşeu ym. 2007). Kommunikointiin liittyvien taitojen kehittyminen voidaan nähdä Binkleyn ja tutkijaryhmän (2012) jaottelussa heijastavan useita eri osaamisalueita: niin konkreettisia työskentelyn taitoja kuin sen välineitä, mutta lopulta myös kykyä paikantaa ja ohjata itseään ja osaamistaan eli taitoja toimia kansalaisena maailmassa.

Keskeiseksi työelämätaidoksi voidaan nostaa myös opiskelijoiden mainitsema rohkeus puhua oman tieteenalansa asiantuntijana. Tähän liittyy luottamus siihen, että ympäristöllä on halua ymmärtää erilaisia tiedon muotoja. Tätä luottamusta puolestaan voidaan nähdä rakennetun kurssilla tieteidenvälisen työskentelyn avulla.

Opiskelijat toivat esiin luovan ideoinnin taidot ja kehittämistaidot, jotka ovat jaottelussa osa ajattelun taitoja. Kaikkiaan ajattelutaidot olivat osa-alue, jota ei tuotu kovin selkeästi esiin. Opiskelijat eivät välttämättä hahmota niitä työelämätaidoiksi vaan ennemminkin sisältöosaamisen piiriin kuuluviksi taidoiksi. On mahdollista, että ajattelutaidot eivät tule heille mieleen, kun heitä pyydetään kuvaamaan oppimaansa ja erittelemään saamiaan työelämätaitoja. Voikin olla, että opiskelijoiden on vaikea sanoittaa osaamistaan, mikä on tullut esille aiemmissa tutkimuksissa (Tuononen ym. 2017, 2019). Tämä näkyy myös siinä, että opiskelijat kuvaavat oppimiaan työelämätaitoja pohdinnoissaan hyvin eri tavoin ja erilaajuisesti. Toisaalta ajattelun taidot tulevat vastauksissa esiin implisiittisesti juuri esimerkiksi uudenlaisten näkökulmien, menetelmien ja erilaisten asiantuntijuuksien tunnistamisessa ja oppimisessa.

Ryhmätyöskentelyyn painottuvilla kursseilla opiskelijoiden kokemukset saattavat erota suurestikin toisistaan, kun ryhmät ovat koostumuksiltaan ja dynamiikoiltaan erilaisia. Tämä variaatio saattaa periaatteessa olla merkityksellinen, kun aineisto rajoittuu kahden kurssin opiskelijoiden kokemuksiin ja näkemyksiin. Toisaalta opiskelijoiden kokemukset työelämätaitojen sisällöistä ja kehittymisestä ovat hyvinkin yhdenmukaisia, mikä osaltaan todentaa monialaisen projektikurssin luonnetta työelämätaitoja kehittävänä oppimisen kontekstina.

Aineistomme on kooltaan pieni, mutta se sisältää monipuolisesti erityyppisiä aineistoja kirjallisine ja suullisine alku- ja loppukyselyineen ja ryhmätöinä laadittuine loppuraportteineen. Aineiston voi siis olettaa antavan luotettavan kuvan opiskelijoiden näkemyksistä työelämätaitojen kehittymisestä. Lisäksi aineiston tulkinnan luotettavuutta lisää oma esiymmärryksemme, joka pohjautuu toimintaamme kurssin opettajina. Opettajuuden kautta olemme saaneet dokumentoidun tutkimusaineiston lisäksi kokemuspohjaista tietoa sekä opiskelijoiden taitojen kehittymisestä että heidän omista reflektioistaan näissä kysymyksissä.

Jotta pystyisimme tarkemmin analysoimaan oppimisen taustalla vaikuttavia mekanismeja, laadullisia menetelmiä voisi yhä laajentaa esimerkiksi etnografisiin menetelmiin. Jatkossa kiinnostavaa olisikin päästä lähemmin tarkastelemaan yhtäältä ryhmäytymisen dynamiikan ja toisaalta kurssilla toteutettujen pedagogisten ratkaisujen vaikutusta oppimisprosessiin (ks. Curşeu ym. 2018; Pluut \& Curşeu 2013; Popov ym. 2012). 


\section{OPISKELIJAT EIV ̈̈T}

\section{V ̈̈LTTÄMÄTT̈̈ HAHMOTA}

\author{
AJATTELUTAITOJA \\ TYÖEL ̈̈MÄTAIDOIKSI.
}

Ilmiöpohjaisen, tieteidenväliseen työskentelyyn ja tiedon käytännölliseen soveltamiseen tähtäävän projektikurssin koettiin aineistomme perusteella kehittäneen kaikkia Binkleyn ja tutkijaryhmän mukaisen jaottelun mukaisia työelämätaitoja. Se, miten nämä kyettiin sanallistamaan, vaihteli eri taitojen ja taitoluokitusten välillä. Opiskelijat pystyivät kaikkiaan tunnistamaan ja erittelemään taitoja, joiden kokivat kehittyneen nimenomaisesti kyseisen kaltaisen projektikurssin kontekstissa.

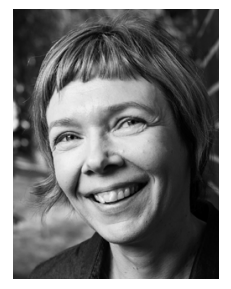

\section{TERHI AINIALA}

$\mathrm{FT}$, dosentti, suomen kielen yliopistonlehtori suomalais-ugrilainen ja pohjoismainen osasto Helsingin yliopisto

(D) https://orcid.org/0000-00034998-9983

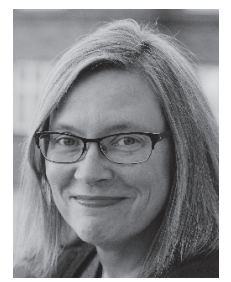

PIA OLSSON

FT, dosentti, kansatieteen

yliopistonlehtori

kulttuurien osasto

Helsingin yliopisto

(D) https://orcid.org/0000-00021736-8333
Kurssejamme määrittäneet attribuutit, kuten ilmiöpohjainen, tieteidenvälinen ja tietoa soveltava, näyttävät kaikki tuoneen oman lisänsä kehittyneiksi koettuihin työelämätaitoihin. Laajemmalla aineistolla voisi olla mahdollista hahmottaa selkeämmin erityyppisten projektikurssien tarjoamia mahdollisuuksia eri työelämätaitojen oppimiseen. Tutkimuksemme pohjalta toteamme, että silloin kun työelämätaidot kumpuavat omasta tieteenalakohtaisesta osaamisesta, hälvenee jännite työelämätaitojen ja tieteenalakohtaisten taitojen välillä. Samalla oman tieteenalan asiantuntijuus paikantuu suhteessa asiantuntijuuden laajempaa kenttää. Onnistuneimmillaan laaja-alainen projektikurssi voi tarjota siltoja erilaisten taitojen merkitysten ja niiden toisiinsa kytkeytymisen ymmärtämiseen ja näin kehittää akateemista asiantuntijuutta.

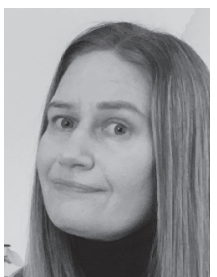

\section{HANNA MATTILA}

TkT, maankäytön suunnittelun yliopistonlehtori rakennetun ympäristön laitos Aalto-yliopisto

(iD https://orcid.org/0000-00021911-7618

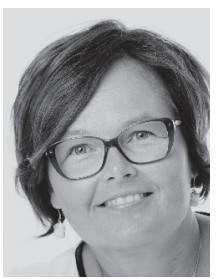

\section{MARJO VESALAINEN}

$\mathrm{FT}$, opetusneuvos korkeakoulu- ja tiedepolitiikan osasto

Opetus- ja kulttuuriministeriö

(iD https://orcid.org/0000-00020055-0155

${ }^{1}$ Binkleyn ym. (2012) neljä taitojen kategoriaa on suomennettu myös seuraavasti: 1) tapa ajatella, 2) tapa työskennellä, 3) työvälineiden hallinta ja 4) kansalaisena maailmassa (Norrena 2013).

${ }^{2}$ Ajanhallintataidot ja stressinsietokyky sijoittuvat Binkleyn ym. (2012) mallissa paikantamisen taitoihin, mutta mielestämme se kuuluu pikemmin työskentelyn taitoihin.

${ }^{3}$ Kirjainlyhenteet esimerkkien perässä suluissa osoittavat, mistä aineistolähteestä vastaukset ovat. $\mathrm{H}=\mathrm{Hakaniemi-}$ kurssin palautekyselyt (2017), H Ir = Hakaniemi-kurssin loppuraportit (2017), M = mobiliteetti-kurssin palautekyselyt (2019), M Ik = mobiliteetti-kurssin loppukeskustelu. 
Barrie, S. C. (2006). Understanding what we mean by the generic attributes of graduates. Higher education 51 , 215-241.

Bergsmann, E., Schultes, M.-T., Winter, P., Schober, B. \& Spiel, C. (2015). Evaluation of competence-based teaching in higher education: From theory to practice. Evaluation and Program Planning 52, 1-9.

Biggs, J. \& Tang, C. (2011). Teaching for quality learning at university. Maidenhead: McGraw Hill Education \& Open University Press Imprint.

Binkley M., Erstad, O., Herman, J., Raizen, S., Ripley, M., Miller-Ricci, M. \& Rumble, M. (2012). Defining twentyfirst century skills. Teoksessa P. Griffin, B. McGaw. \& E. Care (toim.) Assessment and teaching of 21st century skills. Dordrecht: Springer, 17-66.

Cantor, A., DeLauer, V., Martin, D., \& Rogan, J. (2015). Training interdisciplinary "wicked problem" solvers: applying lessons from HERO in community-based research experiences for undergraduates. Journal of Geography in Higher Education 39(3), 407-419.

Curşeu, P. L., Chappin, M. M. H. \& Jansen, R. J. G. (2018). Social Psychology of Education 21(2), 289-302.

Curşeu, P. L., Schruijer, S., \& Boroș, S. (2007). The effects of groups' variety and disparity on groups' cognitive complexity. Group Dynamics: Theory, Research, and Practice 11(3), 187-206.

García-Aracil, A. \& Velden, van der, R. (2008). Competencies for young European higher education graduates: labor market mismatches and their payoffs. Higher Education 55, 219-239.

Grant, M. M. (2011). Learning, beliefs, and products: Students' perspectives with project-based learning. Interdisciplinary Journal of Problem-Based Learning 5(2), 37-69.

Harpe, de la, B., Radloff, A. \& Wyber, J. (2000). Quality and generic (professional) skills. Quality in Higher Education, 6(3), 231-243.

Helle, L., Tynjälä, P. \& Olkinuora, E. (2006). Project-based learning in post-secondary education - theory, practice and rubber sling shots. Higher Education 51, 287-314.

Hyytinen, H. (2015). Looking beyond the obvious: Theoretical, empirical and methodological insights into critical thinking. Helsinki: University of Helsinki. http:// urn.fi/URN:ISBN:978-951-51-0308-6.

Jacob, W. J. (2015). Interdisciplinary trends in higher education. Palgrave Communications 1, 15001 (2015).

Jones, A. (2009). Generic attributes as espoused theory: the importance of context. Higher Education 58, 175-191.

Jääskelä, P., Nykänen, S. \& Tynjälä, P. (2018). Models for the development of generic skills in Finnish higher education. Journal of Further and Higher Education 42(1), 130-142.
Klaassen, R. G. (2018). Interdisciplinary education: a case study. European Journal of Engineering Education 43(6), 842-859.

Koenen, A.-K., Dochy, F. \& Berghmans, I. (2015). A phenomenographic analysis of the implementation of competence-based education in higher education. Teaching and Teacher Education 50, 1-12.

Koh, J. H. L., Herring, S. C. \& Hew, K. F. (2010). Projectbased learning and student knowledge construction during asynchronous online discussion. Internet and Higher Education 13, 284-291.

Krajcik, J. S. \& Namsoo, S. (2014). Project-based learning. Teoksessa Sawyer, R. K. (toim.) The Cambridge Handbook of the Learning Sciences. New York: Cambridge University Press, 275-297.

Kullaslahti, J. \& Yli-Kauppila, A. (toim.). (2014). Osaamisperustaisuudesta tekoihin. Osaamisperustaisuus korkeakouluissa (ESR) -hankkeen loppujulkaisu. Turku: Turun yliopiston Brahea-keskus.

Kurlin, A., Suorsa, O., Carver, E. \& Taulu, H. (2018). Yliopistojen maisteri- ja tohtoriuraseurantakyselyiden 2017 tulokset. Yliopistojen työelämä- ja urapalveluiden Aarresaari-verkosto. https://www. aarresaari.net/download/89/uraseurantojen_2017_ raportti/pdf.

Lattuca, L. R., Voigt, L. J., \& Fath, K. Q. (2004). Does Interdisciplinarity Promote Learning? Theoretical Support and Researchable Questions. The Review of Higher Education 28(1), 23-48.

Lonka, K. (2015). Oivaltava oppiminen. Helsinki: Otava.

Lonka, K., Hietajärvi, L, Hohti, R., Nuorteva, M., Rainio, A. P., Sandström, N., Vaara, L. \& Westling S. K. (2015). Ilmiölähtöisesti kohti innostavaa oppimista. Teoksessa Cantell, H. (toim.) Näin rakennat monialaisia oppimiskokonaisuuksia. Jyväskylä: PS-kustannus, 49-76.

Mattila, H. (2009). Neljä vuosikymmentä yhdyskuntasuunnittelijoiden akateemista täydennyskoulutusta - Miten tästä eteenpäin? Yhdyskuntasuunnittelu 46(4), 25-29.

Mattila, H. (2013). Akateemista maankäytön suunnittelun tutkintokoulutusta viimein Suomeen. Uuden pääaineen suunnittelu ja käynnistäminen Aalto-yliopistossa. Teoksessa Lampinen, M. (toim.) Opettajan muuttuvat roolit. Yhdessä yhteisölliseen opetuksen kehittämiseen. Aalto-yliopiston julkaisusarja CROSSOVER 17/2013. Helsinki: Aaltoyliopisto, 151-168.

Mattila, H. \& Mynttinen, E. (2011). Akateemista alueja yhdyskuntasuunnittelun täydennyskoulutusta muuttuvissa työympäristöissä. Teoksessa I. Gröhn (toim.) Oppisopimustyyppisen täydennyskoulutuksen mallia etsimässä. Turku: Turun yliopisto/Brahea. 33-38. 
Mattila, H., Mynttinen, E., and Mäntysalo, R. (2012) Managing planning pathologies: An educational challenge of the new apprenticeship programme in Finland. Planning Theory \& Practice 13(3), 484-488.

Mikkeli, H. \& Pakkasvirta, J. (2007). Tieteiden välissä. Johdatus monitieteisyyteen, tieteidenvälisyyteen ja poikkitieteisyyteen. Helsinki: WSOY Oppimateriaalit.

Mäkinen, M. \& Annala, J. (2012). Osaamisperustaisen opetussuunnitelman kahdet kasvot. Teoksessa M. Mäkinen, J. Annala, V. Korhonen, S. Vehviläinen, A.M. Norrgrann, P. Kalli,. \& P. Svärd (toim.) Osallistava korkeakoulutus. Tampere: Tampereen yliopistopaino, 127-151.

Norrena, J. (2013). Opettaja tulevaisuuden taitojen edistäjänä. Jyväskylä: Jyväskylä University Printing House.

Nykänen, S. \& Tynjälä, P. (2012). Työelämätaitojen kehittämisen mallit korkeakoulutuksessa. Aikuiskasvatus 32(1), 17-28.

Patria, B. (2014). The effects of learning environment on graduates' competencies. International Journal of Research Studies in Education 3(1), 49-62.

Pitman, T. \& Broomhall, S. (2009). Australian universities, generic skills and lifelong learning. International Journal of Lifelong Education 28(4), 439-458.

Pluut, H. \& Curşeu, P. L. (2013). The role of diversity of life experiences in fostering collaborative creativity in demographically diverse student groups. Thinking Skills and Creativity 9, 16-23.

Popov, V., Brinkman, D., Biemans, H. J. A., Mulder, M., Kuznetsov, A. \& Noroozi, O. (2012). Multicultural student group work in higher education: An explorative case study on challenges as perceived by students. International Journal of Intercultural Relations 36(2), 302-317.

Puustinen, S. (2004). Yhdyskuntasuunnittelu ammattina. Suomalaiset kaavoittajat ja 2000-luvun haasteet. Helsinki: Ympäristöministeriö.

Rittel, H. \& Webber, M. (1973) Dilemmas in a general theory of planning. Policy Sciences 4(2), 155-169.

Räty, H., Komulainen, K., Harvorsén, C., Nieminen, A. \& Korhonen, M. (2018). University students' perceptions of their 'ability selves' and employability: a pilot study. Nordic Journal of Studies in Educational Policy 4(2), 107-115.

Spelt, E. J. H., Biemans, H. J. A., Tobi, H., Luning, P. A. \& Mulder, M. (2009). Teaching and learning in interdisciplinary higher education: a systematic review. Educational Psychological Review 21, 365378.

Teichler, U. (2007). Does higher education matter? Lessons from a comparative graduate survey. European Journal of Education 42(1), 11-34.
Tomlinson, M. (2008). 'The degree is not enough': students' perceptions of the role of higher education credentials for graduate work and employability. British Journal of Sociology of Education 29(1), 49-61.

Tuomi, J. \& Sarajärvi, A. (2009). Laadullinen tutkimus ja sisällönanalyysi. Helsinki: Tammi.

Tuononen, T., Kangas, T., Carver, E. \& Parpala, A. (2019). Yliopisto-opintojen anti viisi vuotta valmistumisen jälkeen - Tukivatko yliopistoopinnot työelämätaitojen kehittymistä työuran näkökulmasta? Yliopistopedagogiikka 26(1).

Tuononen, T., Parpala, A. \& Lindblom-Ylänne, S. (2017). The transition from university to working life - An exploration of graduates perceptions of their academic competences. Teoksessa E. Kyndt, V. Donche, K. Trigwell \& S. Lindblom-Ylänne (toim.) Higher Education Transitions - Theory and Research. London: Routledge, 238-253.

Tymon, A. (2013). The student perspective on employability. Studies in Higher Education 38(6), 841-856.

Uiboleht, K., Karm, M. \& Postareff, L. (2018). The interplay between teachers' approaches to teaching, students' approaches to learning and learning outcomes: a qualitative multi-case study. Learning Environments Research 21(3), 321-347.

Uiboleht, K., Karm, M. \& Postareff, L. (2019). Relations between students' perceptions of the teachinglearning environment and teachers' approaches to teaching: a qualitative study, Journal of Further and Higher Education 43(10), 1456-1475.

Ursin, J. \& Hyytinen, H. (2010). Mitä korkeakoulutuksessa opitaan? Esimerkkinä AHELO. Teoksessa Laukkanen, R. (toim.) PISA, PIAAC, AHELO. Miksi ja miten OECD mittaa osaamista? Opetus- ja kulttuuriministeriön julkaisuja 2010:17, 65-70.

Vaatstra, R. \& Vries, de, R. (2007). The effect of the learning environment on competences and training for the workplace according to graduates. Higher Education 53(3), 335-357.

Vermeulen, L. \& Schmidt, H. G. (2008). Learning environment, learning process, academic outcomes and career success of university graduates. Studies in Higher Education 33(4), 431-451.

Vesterinen, P. (2001). Projektiopiskelu ja -oppiminen ammattikorkeakoulussa. Jyväskylä: University Library of Jyväskylä.

Virtanen, A. \& Tynjälä, P. (2013). Kohti työelämätaitoja kehittävää yliopistopedagogiikkaa - opiskelijoiden näkökulma. Yliopistopedagogiikka 20(2), 2-10.

Virtanen, A. \& Tynjälä, P. (2018). Factors explaining the learning of generic skills: a study of university students' experiences. Teaching in Higher Education, DOI: 10.1080/13562517.2018.1515195. 